Historic, Archive Document

Do not assume content reflects current scientific knowledge, policies, or practices. 



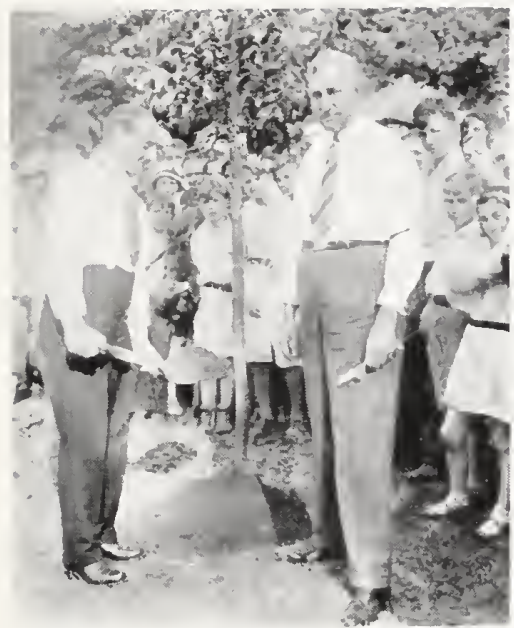

An international tree planting ceremony in City Park. Reading. Pa.. in September 1931. Tree being planted by Lord Mayor of Reading. England. and furnished by Farr Nursery Co. Will you plant a tree in commemoration of the Washington Bicentennial?
Return Postage Guaranteed by

Farr Nursery Co., Weiser Park, P.

Section $4351 \frac{1}{2}$ P. L. \& R.

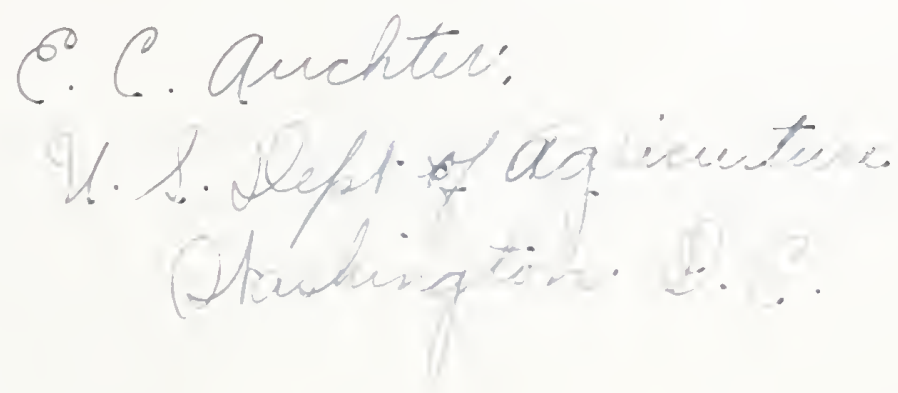

BETTER PLANTS-March, 1932 



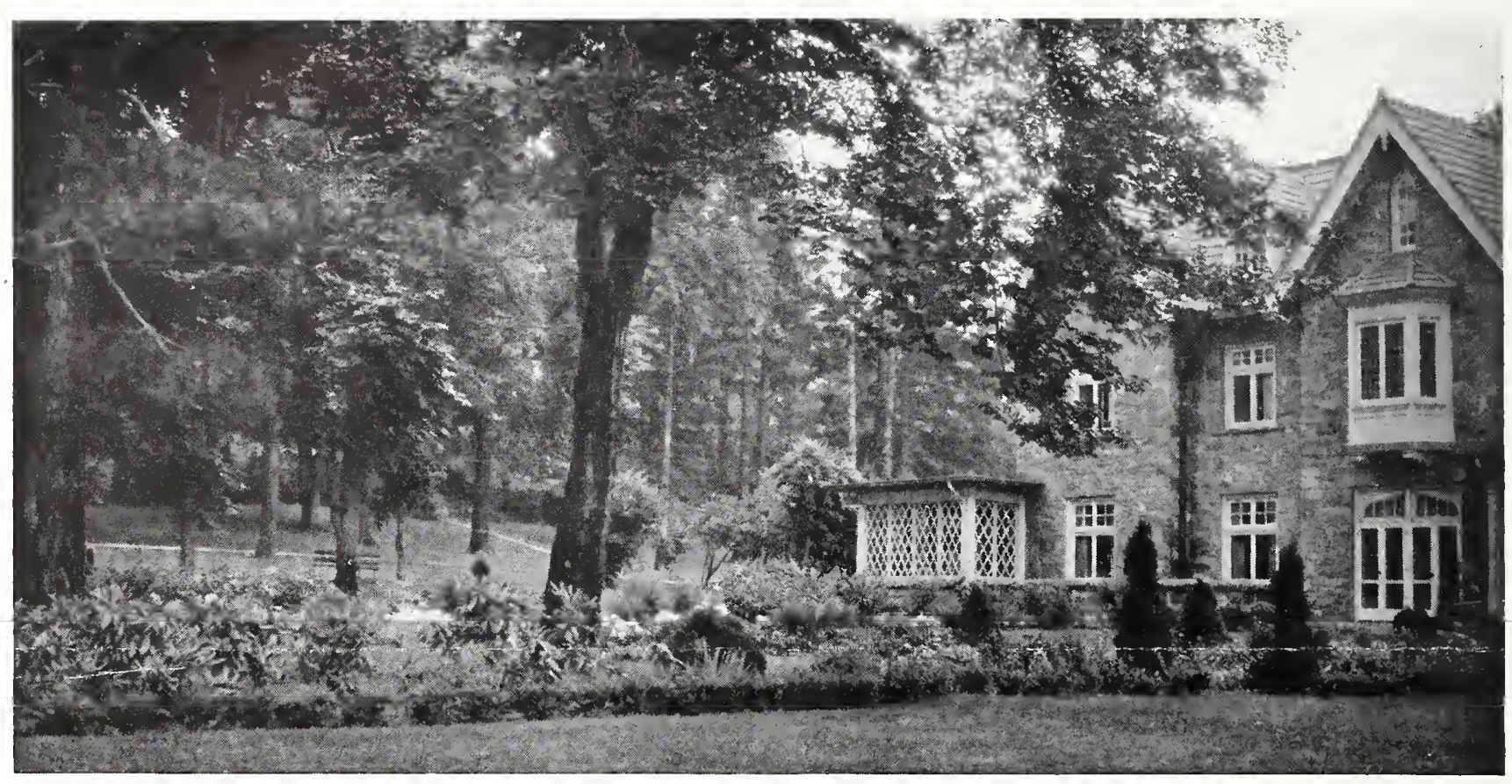

RESIDENCE OF JOHN H. PERRY, IRVINGTON - ON - THE - HUDSON

Landscape plans for 10 acres executed by Farr Landscape Department during 1929, 1930 and 1931. In a recent and unsolicited letter Mr. Perry says: "I think next spring you will see such a gorgeous coloring in my place, that I will have many. many inquiries as to where I purchased my plantings, and it will be a genuine delight for me to tell about the aid and advice which your Landscape Department rendered, and the high quality of your stock."

\section{Flowering Apples}

The Flowcring Apple is referred to as "Queen of the Garden" by the Arnold Arboretum, and should be first on the Iist of flowering trees. In spring. the gorgeous masses of bloom; then the shiny, glossy green, clean bank of foliage; and in fall, clusters of smalI, colorful fruit.

While the trees are as hardy as the wild apple, they will appreciate culture They are of slow, spreading growth, lending themselves to trimming, and will not outgrow even the average small garden. Note discounts on page 3.

Arnoldiana. Semi-double, pink flowers on long red stems, yellow fruit. 4 to $5 \mathrm{ft}$., $\$ 2$ each.

Atrosanguinea. Brilliant carmine blooms, fading pink, completely hide twigs and foliage, and last two weeks. 4 to $5 \mathrm{ft}$., $\$ 2$ each

Bechtel's. Double; pink, fragrant, late. Like a trce of double roses 3 to $4 \mathrm{ft}, \$ 1.50$ each.

Parkinani. Double; pink Dwarf and just right for small gardens. 4 to $5 \mathrm{ft}$, $\$ 2$ each.

Purpurea. Red foliage, bark, flowcrs, and fruit 4 to $5 \mathrm{ft}$., $\$ 2$ each.

Scheideckeri. Abundant, semi-double pink blooms. 4 to $5 \mathrm{ft}, \$ 2$ each.

Toringo. White flowers; showy red fruit, loved by the birds. Low growing. 4 to $5 \mathrm{ft}, \$ 2$ each

NOTE.-1932 discounts, page 3, are applicable on above prices

\section{Normandy Crab Collection}

One each of above 7 varieties, in size listed (value $\$ 13.50$ ), for $\mathbf{\$ 1 0}$ Less 10 per cent if "cash with order,' by March 20 . No other discounts

\section{Do's and Don'ts for Lawns}

Don't mow too closely, especially in Avoid daily Iawn wetting. When it besummer, Mowing high and often is the first essential to a good lawn.

Don't remove grass clippings. Mow often enough so it will be unnecessary.

Don't add lime to a Iawn unless you are sure it is nccessary. Lime encourages most lawn weeds

A certain amount of reseeding is necessary every year evcn for the famous century-oId lawns. Early spring and early fall are the best seasons

\footnotetext{
Looking for Spring The Cherry trees seem to be splendid, healthy specimens, and very good size. We are look ing forward to the sprin. blossom time, GARDEN SECTION OF THE WO Reading, $\mathrm{Pa}$. 11-17-31 He Ouglit to Know Please send your catalog used to work for you and $l$ am anxious to get one of your eatalogs, knowing what wonderful stock you earry-Harry A BECK, River Rouge, Mich

A Perfect

Testimonial

The Garden Club of Lookout Mountain has just received a shipment from you. The bushes were very niee, and on the strength of the good condition am sendin you my order - Mrs JEROME B. Pound, Lookout Mountain, \begin{tabular}{l} 
Lookout Mountain \\
Tenn. \\
\hline
\end{tabular}

RADI0 BROADCAST Each Thursday, 12:15 P.M STATION WEEU Reading
} comes too dry, apply the sprinkler twice a wcek to each spot for at least several hours, or until soil is watered to a depth of several feet. Daily drenching does much more harm than good.

Keep the lawn weII fed. Apply three pounds of Vigoro per 100 square feet at 60-day intcrvals, from March to September. Roll the lawn cach spring, whilc soil is pliable, for the sake of the grass and your lawn mower (Continued on page 3)

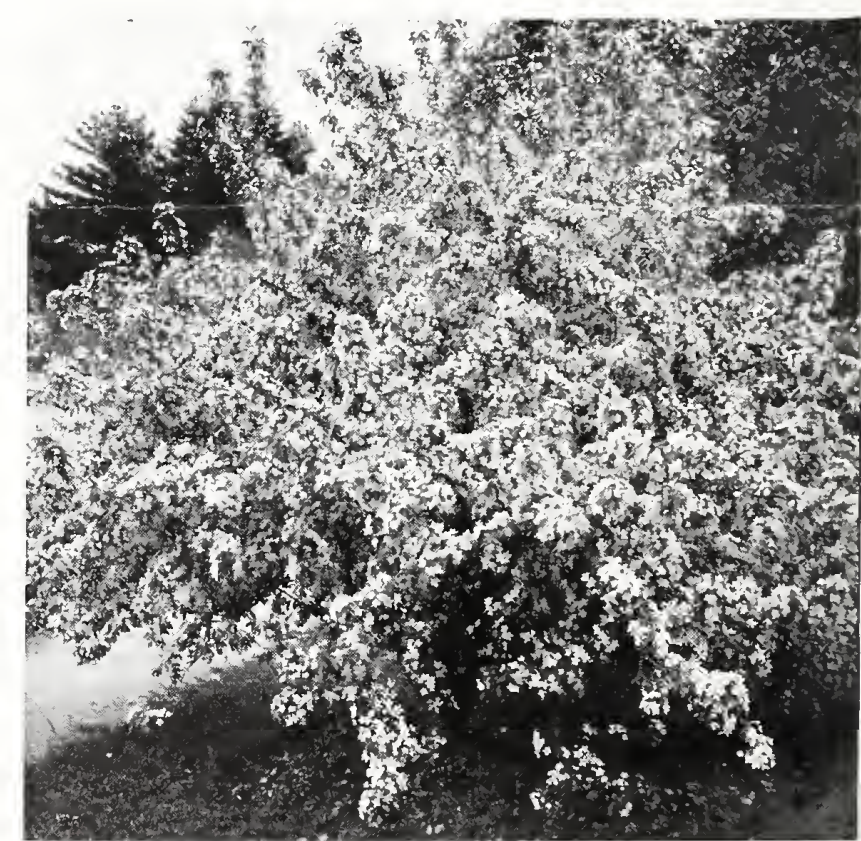

Malus atrosanguinea A mass of bloom from Farr's well-grown specimen trees 


\section{Novelty Philadelphus Without Novelty Prices LEMOINE CREATIONS}

We bclieve that no other man ever produced as worth-while a list of ornamental plants as the Iate Mons. Lcmoine, of France. He lacked only American press agents to makc him the botanical figure of a century. His creations, by sheer merit and without any deliberate publicity, have won and held a place in nurseries and gardens, internationally, for the past twent $y$-five vears. His interest included Lilacs, Peonies, Trce Pconies, Deutzias, Philadelphus, and other shrubs and perennials.

Why not add a collcction of Lemoine Philadelphus to your garden? Why not add an abundance of them and rip out some of the overgrown or tiresome shrubbery you may now possess? At thesc 1932 prices the cost is a small obstacle, and the choiceness and novelty of the new Philadelphus will be of as much satisfaction as if you had paid $\$ 5$ per plant a few years ago.

Albatre. Large, full, double, pure white; dense panicles. 2 to $3 \mathrm{ft}$., 75 ets. each; 5 or morc at $60 \mathrm{cts}$.

Argentine. Erect-growing, with clusters of double, pure white flowcrs, more than 2 inches across. Medium grower. 2 to $3 \mathrm{ft}$., $\$ 1$ each; 5 or more at 75 cts.

Avalanche. Large, fragrant flowers on graceful, arching branches. Medium growcr. 2 to $3 \mathrm{ft}$., $60 \mathrm{cts}$. each; 5 or more at $50 \mathrm{cts}$.

Boule Rose. Medium compact shrub with large foliage. Flowers white, fragrant, and double, $11 / 2$ to 2 inches across. 2 to $3 \mathrm{ft}$., $75 \mathrm{cts}$. each; 5 or more at $60 \mathrm{cts}$.

Bouquet Rose. Large, double white blooms, $11 / 2$ inches in diameter, more double than Boule Rose. 2 to $3 \mathrm{ft}$, $75 \mathrm{cts}$. each; 5 or more at $60 \mathrm{cts}$.

Glacier. Strong, erect grower with clusters of double white flowers, each having the appearance of one enormous double flower. 2 to $3 \mathrm{ft}, 75 \mathrm{cts}$. each; 5 or more at $60 \mathrm{cts}$.

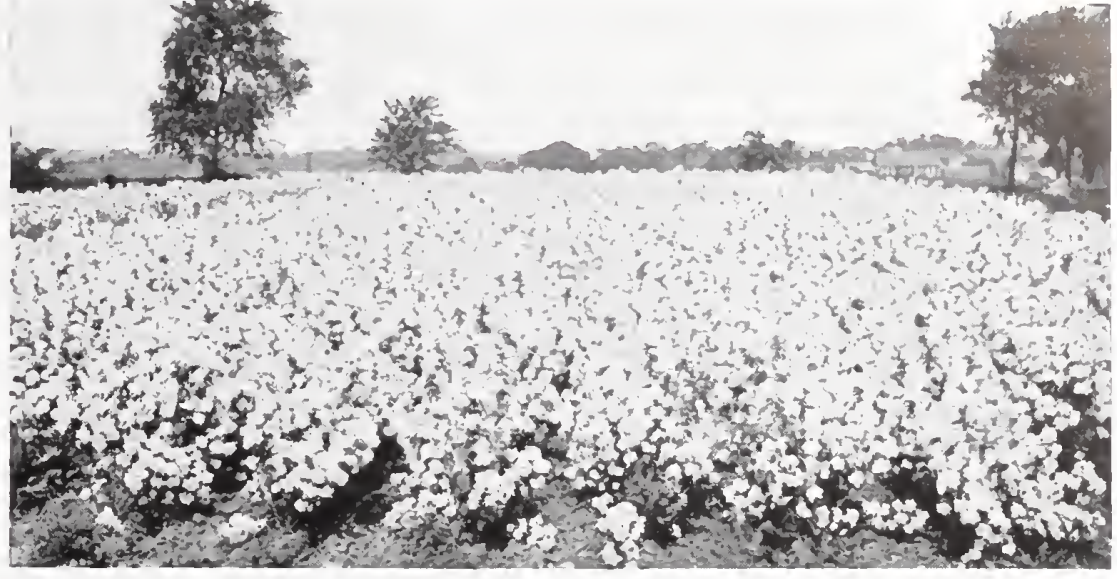

A block of Philadelphus Virginal in our nursery during June, 1931. All plants pruned and trained into bushy, uniform specimens.
Mont Blanc. Fragrant, single flowers on slender branches. Small foliage. 2 to $3 \mathrm{ft}$., $60 \mathrm{cts}$. each; 5 or more at $45 \mathrm{cts}$.

Norma. Large, single to semi-double, fragrant blooms in May and June. Tall. 2 to $3 \mathrm{ft}$., $60 \mathrm{cts}$. each; 5 or more at $45 \mathrm{cts}$.

Splendens. Large, white, semi-double, fragrant flowers in clusters. Dwarf and spreading. 2 to $3 \mathrm{ft}$., 75 cts. each; 5 or more at 60 cts.

Virginal (Virginal Mock-Orange). Semidouble, white flowcrs produced intermittently all summer. Medium grower. 2 to $3 \mathrm{ft} ., 75 \mathrm{cts}$. each; 5 or more at $60 \mathrm{cts}$.

Voie Lactée. Snow-white, with conspicuous golden stamens. Tall and bushy, with quantities of immense flowers. Late. 3 to $4 \mathrm{ft}$., $75 \mathrm{cts}$. each; 5 or more at $60 \mathrm{cts}$.

NOTE. 1932 discounts on this page are applicable on above prices

\section{Lemoine Collection}

One plant each of the above 11 varieties, (amounting to $\$ 8.05$ ) for $\$ 6$ "charge," or $\$ 5.50$ cash with order. No further discounts.
Our Garden House will probably be open to visitors during all daylight hours beginning March 15 to 20, depending on the season. The Display Garden will include 38,000 tulips, narcissi, etc., in almost 200 varieties.

Dandelion Remedy. For 100 square feet of lawn use 11/2 pounds of Iron Sulphate (copperas) to 6 quarts of water. Bruise the foliage first by dragging a steel doormat, etc., over it.

\section{Discounts}

We are using our 1931 prices, with discounts, for 1932. If you do not have a copy of the 1931 Catalog, please ask for one. If you have a copy, please note the following discounts on the cover.

5 per cent on orders exceeding $\$ 2.99$ 10 per cent on orders exceeding $\$ 9.99$ 15 per cent on orders exceeding $\$ 24.99$ 10 per cent for cash with order until

March 15; 3 per cent after that

Examples. Until March 15, a cash

rder amounting to $\$ 3$ will cost $\$ \mathbf{2 . 5 7}$;

$\$ 10$ order, $\$ 8.10$; a $\$ 25$ order, $\$ \mathbf{1 9 . 1 3}$.
Do's and Don'ts for Lawns, continued

Be especially careful about not having the lawn cut too closely when winter arrives. The grass itself should be from 3 to 4 inches in height when the ground freezes. During late fall set the knives of the lawn-mower exceedingly high, and espccially for the last mowing, or do not mow at all for the last few weeks before the ground freezes. More lawns have been ruined through incorrect mowing than for any other reason.

Most lawns were seriously damaged Iast year by extrcme drought. Remedies include resoiling, rolling, resceding, and feeding. Early action produces good lawns ahead of summer wceds and dry spells.
On the Square

Always get first-class stock and service. A pleasure to deal with you.-SAMUEL G. REESE. Methtown, Pa. 10-23-31 Plants Bloomed Quickly

Many persons have omplimented us on the appearance of our piace this summer. I am sure it is due to your land. cape execution about he house. The piants have bloomed and grown wonderfully in so shor: time.-Mrs. G. Don Aid Spackman. Coates.
ville, Pa. 6-18-31

\section{Lawn Seed}

Weiser Park Brand. Composed of clean, short-growing, fine-leaved, fibrous-rooted perennial grasses of highest vitality, which, maturing at different seasons, produce a constantly green and velvety surface. A seientific mixture of Fancy Kentucky Blue Grass, Fancy Redtop, Fescue, White Clover, Timothy and Rye Grass.

25 lbs. at 35c.; 5 lbs. at 40 c. No discounts.

\section{March Half-Price Specials}

\section{All strong, 2-year, field-plants}

\section{Anchusa Myosotidiflora}

Siberian Forget-me-not. A mass of brilliant blue. Superior to mertensia and companion to daffodils. For borders, rockeries, and semi-shade. Attractive foliage.

Catalog price, 5 or more at $\mathbf{4 0} \mathrm{cts}$. each; 25 or more at 35 cts. each.

Divide prices by two if ordered during March.

\section{Astilbe Chinensis}

Large, feathery panicles of silvery pink flowers. Excellent for cut-flower combinations as well as garden display. 5 or more at 40 cts. each; 25 or more at $35 \mathrm{cts}$. each.

Divide prices by two during March.

\section{Iris, Bruno}

One of the finest newer Irises and rated above 90 per cent by American Iris Society. Large, tall, rich, velvety purple.

$\$ 3$ in Catalog. \$1.50 during March. 
Discounts noted on page 3 apply on all items on this page.

Achillea Ptarmica, The Pearl
Long-season white flower in rock-garden or border.
Good for cutting.
25 at 18 c. ea.; 10 at 20 c. ea.; 5 at $\mathbf{2 2 c}$. ea.

\section{Artemisia Lactiflora}

Tall, fragrant, cream-whitc sprays in September. For background and bouquct.

25 at 18c. ea.; 10 at 20c. ea.; 5 at 22c. ea.

\section{Centaurea Macrocephala}

Showy, golden yellow, cut and display flowers in July and August.

25 at 18c. ea.; 10 at 20c. ea.; 5 at 22c. еa.

\section{Chrysanthemum Arcticum}

One of the best fall-bluoning perenniais for borders or rockeries. Smiling Daisies in October. Glossy neat rosettes of foliage.

25 at 16c. ea.; 10 at 18c. ea.; 5 at 20 c. ea.

\section{Gaillardia Aristata}

Ever-blooming yellow and red cut-flowers for border and rockeries.

25 at 16c. ea.; 10 at 18c. ea.; 5 at 20 c. ea.

\section{Hemerocallis, Ophir}

Dark golden yellow Day Lily with extremely large blooms ( 5 inches across) during July and August. Introduced by Farr, and awarded honorable mention at Wisley Field Trials by Royal Horticultural Society in 1931. 10 at 30 c. ea.; 5 at 35 c. ea.; 1 at 50c. ea.

\section{Hollyhocks}

Mixed colors, including all shades. Strong freld-plants. 25 at 16c. ea.; 10 at 18c, ea.; 5 at 20 c. ea.

\section{Iris Collection}

12 Iris in 12 named varieties, wide color-range, (our selcction, all rated above 75 per cent by Iris Society) for \$2; March only.

\section{Lilac, Leon Gambetta}

Best double rosy pink Lilac. Large, free, and vigorous. 2 to $3-\mathrm{ft}$. specimens at $\$ \mathbf{2} .25$ each

\section{Lilac Collection}

Uur choice French Hybrid Lilacs in four named - Il eties, (our selcction), 18 to 24 -in. plants, for $\mathbf{\$} 4$.

Lily-of-the-Valley
3-inch, pot-bound clumps.
25 at 16c. ea.; 10 at 18c. ea.; 5 at 20 c. ea.

\section{Sempervivum}

Assorted types of smaller spccies "Hen and Chickens." 25 at 12c. ea.; 10 at 15c. ea.; 5 at 16c. ea.

\section{Tree Peony, Moutan}

Hardiest and most free-blooming Tree Peony. Single, deep red blooms. Plants bore 4 to 8 blooms in 1931 . 10 to 12 -in. plants at $\$ \mathbf{3}$ each

\section{FARR NURSERY COMPANY}

\section{Weiser Park · Pennsylvania}

